\title{
EFFECT OF ASSISTED TRAINING ON THE SPECIAL RUNNING PREPARATION OF JUNIOR SPRINTERS FOR 100 AND $200 \mathrm{~m}$
}

\author{
H.T. Stoyanov, info@akademik-bg.com, ORCID: 0000-0001-6129-8056 \\ Athletic club AKADEMIK, Sofia, Bulgaria
}

\begin{abstract}
Aim. To test the effect of the assisted training tools on the most important indicators affecting speed development and the results in 100 and 200 min junior sprinters. Particular tasks were chosen to test the effect of assisted training on the development of speed, maximum speed, and speed endurance. Materials and methods. The study included a group of 8 junior athletes and lasted seven weeks (the pre-competition mesocycle -4 weeks; competition mesocycle -3 weeks). The study focused on the assisted training tools having crucial importance for the results in 100 and $200 \mathrm{~m}$. The effect of these tools on the development of speed, sprint, and speed endurance was tested by establishing the correlations between them. Results. The study revealed that using the $30 \mathrm{~m}$ series with assisted training promotedthe maximum speed and start acceleration. There was also a strong correlation between $30 \mathrm{~m}$ assisted speed and the result in $100 \mathrm{~m}$, which indicated that this training tool improved both the starting acceleration and maximum speed development. Also, it was found out that the $200 \mathrm{~m}$ result depended on $30 \mathrm{~m}$ AST run and the $100 \mathrm{~m}$ time. Conclusion. The results showed that using assisted training tools promoted speed development by the improvement of the nervous and muscular capacity in young sprinters.
\end{abstract}

Keywords: assisted training, 100 and $200 \mathrm{~m}$ sprint, maximum speed development, junior sprint athletes.

\section{Introduction}

Speed development in sprints can be defined as a product of the stride length and stride frequency (SL and SF). Increasing the speed of a sprinter in any given phase of a race requires changing one or both variables (SF and/or SL), in a way not affecting neither of the two negatively [3]. The running phases were described and analyzed in detail in the literature by different authors [6, 21, 23, 25].

Sprint running efficiency requires an optimal combination of biomechanical variables dependent on technical execution and the positive impact of external factors $[6,7,19,25]$.

Generating higher speed in the start acceleration phase results in a better time. Along these lines, experts in short sprints are working hard to solve this problem. Some of them propose the implementation of resistant sprint training (RST) (or sled training), the weight of the sled changes according to athlete's weight $[1,5,9-11,16,22]$. Some authors $[8,12,13,22]$ studied the effects of other training methods, including pulling techniques (ropes) in sprint training, on the change in the kinematics of start acceleration, which had a positive impact on speed development.

Coaches are also interested in the effective use of assisted sprint training (AST) as well as in effect, it has on start acceleration and maximum running speed $[3,26]$.

Both specific training methods (RST and AST) are of considerable importance for sprint training: RST helps to cope with resistance thrust and AST - to achieve higher maximum running speed. According to Mero \& Komi [17, 18], RST and AST develop the neuro-muscular potential of the athlete by triggering an additional number of muscle myofibrils as well as neuro-muscular innervation in the working muscles. In our studies [26], both RSP and AST were used to cope with stabilizing maximum running speed.

In training for speed development, one often reaches a level of speed stabilization (plateau), and reaching the next level of running speed is almost impossible. In our study [24], we established that in different training stages, SL and SF could be modified by using different running intensity. Inadequacy (lack of coherence) in the different stages of training programmes could cause worsening of rhythmic running structure and could cause problems with speed development. This allows to state that a precise dosage of training efforts during the different microand mesocycles is essential for reaching balance 
in the development of specific running preparation.

One of the current problems when working with young sprinters is speed development in the different phases of sprint events. This leads us to the use of assisted training in order to improve speed development by affecting both the SL and SF.

The objective of the present study was to assess the effect of assisted training tools on the indicators affecting speed development and results in 100 and 200 min junior sprinters. The following particular tasks were set:

- To analyse the effect of assisted training efforts as a part of the training techniques used for speed development.

- To establish the importance of assisted training techniques used for speed- and sprint endurance development.

- To reveal the effect of assisted training load on the training tools for speed development based on the correlations between them.

- To study the effect of assisted training tools on the development of speed and sprint endurance based on the correlations between them.

\section{Material and methods}

\section{Participants}

The study was carried out during the precompetition mesocycle (4 weeks) and the competition mesocycle (3 weeks). A group of 8 youth and junior athletes with an average age of 17.2 years participated in the study. The data on athletes are presented in Table 1 . The results in $100 \mathrm{~m}$ and $200 \mathrm{~m}$ are achieved at the end of the study. They are obtained by hand timing and $0.24 \mathrm{sec}$ were added to make them comparable to elec- tronic timing. Only the athlete VJ achieved the results at 100 and $200 \mathrm{~m}$ in official starts that coincided with the study period. The structure of weekly training programme is presented in Table 2.

\section{Procedure}

Assisted training is performed traditionally with a special device, which is an elastic rope with a diameter of $10 \mathrm{~mm}$ and a length of $50 \mathrm{~m}$. The athlete places a waist belt with a rope attachment. Upon reaching the set draw strength and after a signal from the coach, the athlete runs the distance. Upon termination of the effective force of the rope during the running, it is released automatically. In the pre-race mesocycle (1st and 2nd microcycles) AST is included in the training process with $30 \mathrm{~m}$ standing start series. The rope is stretched by the coach through applying different levels of force (86-87 N, and 104-105 N) to achieve $102-103 \%$, and $108-100 \%$ assisted running speed, respectively, for $30 \mathrm{~m}$ standing start. In $50 \mathrm{~m}$ standing start, the applied force was $104-105 \mathrm{~N}$ and $192-193 \mathrm{~N}$ for achieving $103-104 \%$ and $108-100 \%$ assisted running speed, respectively.

Assisted training efforts took place two times a week on speed training days, starting with $30 \mathrm{~m}$ run - standing start AST. After reaching satisfactory speed, the athletes moved on $50 \mathrm{~m}$ standing start AST. During the first training sessions, the assisted speed was not more than $103 \%$ of the current maximum speed of a given athlete. After reaching the required adaptation to assisted running at $30 \mathrm{~m}$ the athletes stepped on to $50 \mathrm{~m}$ AST. During the $30 \mathrm{~m}$ runs speed can reach as much as $108-110 \%$, but during the $50 \mathrm{~m}$ runs speed should not be more than 103-104\%.

Qualification characteristics of the studied athletes

Table 1

\begin{tabular}{|c|c|c|c|c|c|c|c|c|c|}
\hline \multirow{3}{*}{$\begin{array}{l}\text { Athletes } \\
\text { (initials) }\end{array}$} & \multicolumn{8}{|c|}{ Indices } & \multirow[b]{3}{*}{$\begin{array}{c}\text { Result } \\
(\mathrm{m} / \mathrm{s})\end{array}$} \\
\hline & \multirow[b]{2}{*}{$\begin{array}{l}\text { Height } \\
\text { (cm) }\end{array}$} & \multirow[b]{2}{*}{$\begin{array}{c}\text { Weight } \\
\text { (кg) }\end{array}$} & \multirow[b]{2}{*}{$\begin{array}{c}\text { Year } \\
\text { of Birth }\end{array}$} & \multicolumn{2}{|c|}{ Result } & \multirow[b]{2}{*}{$\begin{array}{c}\text { Training } \\
\text { (years) }\end{array}$} & \multicolumn{2}{|c|}{ Experience } & \\
\hline & & & & $100 \mathrm{~m}(\mathrm{~s})$ & $200 \mathrm{~m}(\mathrm{~s})$ & & Distance & $\begin{array}{l}\text { Average } \\
\text { result (s) }\end{array}$ & \\
\hline V.J. & 176 & 62 & 2001 & 10.62 & 21.36 & 4 & $30 \mathrm{~m}$ & 3.73 & 8.04 \\
\hline T. S. & 184 & 68 & 2001 & 10.92 & 21.82 & 3 & $50 \mathrm{~m}$ & 5.77 & 8.66 \\
\hline R. V. & 178 & 65 & 2000 & 10.88 & 21.74 & 3 & $30 \mathrm{~m} \mathrm{AST}^{1)}$ & 3.45 & 8.69 \\
\hline M. J. & 178 & 62 & 2001 & 11.15 & 22.60 & 4 & $50 \mathrm{~m} \mathrm{AST}^{1)}$ & 5.36 & 9.33 \\
\hline I. B. & 186 & 64 & 2002 & 11.12 & 22.48 & 3 & $100 \mathrm{~m}$ & 11.03 & 9.07 \\
\hline A. V. & 179 & 65 & 2000 & 11.25 & 22.82 & 4 & $150 \mathrm{~m}$ & 16.21 & 9.25 \\
\hline A. Z. & 183 & 70 & 2000 & 10.98 & 22.16 & 3 & $200 \mathrm{~m}$ & 21.31 & 8.96 \\
\hline G. D. & 170 & 61 & 2002 & 11.36 & 23.04 & 2 & $300 \mathrm{~m}$ & 34.74 & 8.64 \\
\hline Mean & 179.25 & 64.63 & & 11.04 & 22.25 & 3.25 & & & \\
\hline
\end{tabular}

${ }^{1)}$ Assisted Sprint Training. 


\section{Спортивная тренировка}

Distribution of training tools in the pre-competition mesocycle (I, II, III and IV microcycles) and of assisted training runs in the competition mesocycle

\begin{tabular}{|c|c|c|c|c|}
\hline \multirow{2}{*}{ Day } & \multirow{2}{*}{ Type of training } & \multicolumn{2}{|c|}{ Pre-competition mesocycle } & \multirow{2}{*}{$\begin{array}{c}\text { Competition } \\
\text { mesocycle }\end{array}$} \\
\hline & & I, II and III microcycles & IV microcycle & \\
\hline Monday & Toning workout & \multicolumn{3}{|c|}{ Tempo runs $-85 \%$, toning strength exercises } \\
\hline Tuesday & Speed development & $\begin{array}{l}3 \times 30 \mathrm{~m}-\text { high frequency } \\
\text { running; } \\
2 \times 30 \mathrm{~m}-\text { series flying start; } \\
2 \times 30 \mathrm{~m} \text { and } 1 \times 50 \mathrm{~m}- \\
\text { series standing start; } \\
2 \times 30 \mathrm{~m}-\text { AST running; } \\
\text { Total volume for speed } \\
\text { training }-300-400 \mathrm{~m}\end{array}$ & $\begin{array}{l}\text { As the previous ones } \\
+ \text { AST running } \\
1 \times 30 \mathrm{~m}- \\
(108-110 \%) \\
1 \times 50 \mathrm{~m}- \\
(103-104 \%)\end{array}$ & $\begin{array}{l}\text { As the previous ones } \\
+ \text { AST running } \\
1 \times 30 \mathrm{~m}- \\
(108-110 \%)+ \\
1 \times 50 \mathrm{~m}- \\
(108-110 \%)\end{array}$ \\
\hline Wednesday & $\begin{array}{l}\text { Sprint and sprint } \\
\text { endurance }\end{array}$ & \multicolumn{3}{|c|}{ Development of sprint and speed endurance } \\
\hline Thursday & Strength development & \multicolumn{3}{|c|}{ Exercises with hurdles. Strength training } \\
\hline Friday & Speed development & $\begin{array}{l}3 \times 30 \mathrm{~m}-\text { high frequency } \\
\text { running; } \\
2 \times 30 \mathrm{~m}-\text { series flying start; } \\
2 \times 30 \mathrm{~m} \text { and } 1 \times 50 \mathrm{~m}-\text { series } \\
\text { standing start; } \\
3 \times 30 \mathrm{~m}-\text { AST running }\end{array}$ & $\begin{array}{l}\text { As the previous ones } \\
+ \text { AST running } \\
2 \times 30 \mathrm{~m}(108-110 \%) \\
+1 \times 50 \mathrm{~m}- \\
(103-104 \%)\end{array}$ & $\begin{array}{l}\text { As the previous ones } \\
+ \text { AST running } \\
1 \times 30 \mathrm{~m} \\
+2 \times 50 \mathrm{~m}- \\
(108-110 \%)\end{array}$ \\
\hline Saturday & $\begin{array}{l}\text { Speed and strength } \\
\text { endurance }\end{array}$ & \multicolumn{3}{|c|}{$\begin{array}{l}\text { Development of speed endurance. } \\
\text { Strength endurance }\end{array}$} \\
\hline
\end{tabular}

Evidence by which one can see the speed barrier is hand miscoordination and measuring the stride length in the middle of the distance and in the last meters of the distance. The difference is a result of the quickly tiring neuro system and the muscles of the back part of the leg.

\section{Results and Discussion}

The analysis of the correlation matrix (Table 3) revealed the correlations between standing starts of $30 \mathrm{~m}$ and $50 \mathrm{~m}$ and the $30 \mathrm{~m}$ assisted run, expressed by high correlation coefficients $(\mathrm{R}=0.92$ and $\mathrm{R}=0.91$, respectively). Increasing the speed during start acceleration is of crucial importance both for reaching maximum speed and for the final result. Importantly, we noticed a significant correlation between the speed of $30 \mathrm{~m}$ AST and the result in the $100 \mathrm{~m}(\mathrm{R}=0.97)$ test. The high correlation coefficient proves the statement of several experts like $[2,4,6]$ who noted the importance of the start and start acceleration phases as the main factor, affecting the final result. The second most important factor affecting the result in $100 \mathrm{~m}$ is the development of sprint endurance by running $150 \mathrm{~m}$, expressed by the high correlation coefficient $(\mathrm{R}=0.86)$. The $50 \mathrm{~m}$ standing start turned out to correlate with the same magnitude $(\mathrm{R}=0.86)$.

The relationship between the two assisted training runs of $30 \mathrm{~m}$ and $50 \mathrm{~m}$ was also high $(\mathrm{R}=0.835)$. It could be supposed that the $50 \mathrm{~m}$ AST run helps to reach assisted training speed of $108-110 \%$ in the $30 \mathrm{~m}$ effort. Following this sequence in speed development is of considerable importance.

The close correlation between the results in $100 \mathrm{~m}$ and $200 \mathrm{~m}(\mathrm{R}=0.95)$ is well known. This relationship shows that the training of athletes should aim at participating in both sprint events. High results in the $100 \mathrm{~m}$ run help reaching high results in the $200 \mathrm{~m}$ run and vice versa.

The final results in $200 \mathrm{~m}$ are most influenced by $30 \mathrm{~m}$ AST speed, expressed by the significant correlation coefficient $(\mathrm{R}=0.96)$. Probably the correlation between the abovementioned training techniques, start acceleration, and maximum speed has a positive impact on the $200 \mathrm{~m}$ run. Importantly, endurance development in $200 \mathrm{~m}$ and $100 \mathrm{~m}$ demonstrates a strong relationship $(\mathrm{R}=0.889)$. The third most important factor is the $30 \mathrm{~m}$ (standing start) run with the correlation ratio of $\mathrm{R}=0.87$. According to several experts $[6,14,15,20]$ start acceleration can influence the final result significantly, and according to our own experience, it is by $15-20 \%$. Here we should note that the wrong development of speed dynamics in start acceleration, especially in young sprinters, leads to unsatisfactory results. 
Relationships between the training tools used, expressed by a correlation coefficient

Table 3

\begin{tabular}{|l|l|l|l|l|l|l|l|l|}
\hline & $30 \mathrm{~m}$ & $50 \mathrm{~m}$ & $30 \mathrm{~m}^{*}$ & $50 \mathrm{~m}^{*}$ & $100 \mathrm{~m}$ & $150 \mathrm{~m}$ & $200 \mathrm{~m}$ & $300 \mathrm{~m}$ \\
\hline $30 \mathrm{~m}$ & 1.000 & & & & & & & \\
\hline $50 \mathrm{~m}$ & 0.924 & 1.000 & & & & & & \\
\hline $30 \mathrm{~m}^{*}$ & 0.916 & 0.908 & 1.000 & & & & & \\
\hline $50 \mathrm{~m}^{*}$ & 0.806 & 0.796 & 0.835 & 1.000 & & & & \\
\hline $100 \mathrm{~m}$ & 0.838 & 0.860 & 0.971 & 0.793 & 1.000 & & & \\
\hline $150 \mathrm{~m}$ & 0.959 & 0.867 & 0.903 & 0.767 & 0.864 & 1.000 & & \\
\hline $200 \mathrm{~m}$ & 0.873 & 0.824 & 0.963 & 0.791 & 0.954 & 0.889 & 1.000 & \\
\hline $300 \mathrm{~m}$ & 0.955 & 0.808 & 0.823 & 0.666 & 0.728 & 0.923 & 0.838 & 1.000 \\
\hline
\end{tabular}

*assisted sprint training (AST).

One of the main issues in young sprinters' training is the development of speed endurance with runs longer than race distance. In our research, we included $300 \mathrm{~m}$ runs, which are very important for the success in $200 \mathrm{~m}$, as demonstrated by the high correlation coefficient $(\mathrm{R}=0.838)$. In the weekly programmes during pre-competition and competition weekly microcycles the development of sprint- and speed endurance are of crucial importance. This statement is proved by the relationship between $150 \mathrm{~m}$ and $300 \mathrm{~m}$ runs, expressed by the correlation coefficient $(\mathrm{R}=0.923)$.

\section{Conclusions}

The analysis shows that the precise dosage of training effort in pre-competition and competition mesocycles and tuning the most appropriate quantity and quality of training efforts provide the base for achieving the necessary balance in the development of special running preparation. This represents an original method that can be used in the training programs for junior athletes.

The results allow making some inferences and recommendations.

1. Using assisted training $30 \mathrm{~m}$ runs helps the development of speed during start acceleration. Assisted training in $30 \mathrm{~m}$ runs also has a positive impact on running $30 \mathrm{~m}$ and $50 \mathrm{~m}$ (standing start) expressed by the high correlation coefficients.

2. The significant and high relationship between $30 \mathrm{~m}$ AST and the result in the $100 \mathrm{~m}$ dash shows that this training technique helps both improving start acceleration and developing maximum speed, which are of crucial importance for the result in $100 \mathrm{~m}$.

3. The analysis revealed that $200 \mathrm{~m}$ result depends on $30 \mathrm{~m}$ AST run and on the $100 \mathrm{~m}$ time.

4. The close values of the correlation coefficients $(\mathrm{R}=0.864)$ and $(\mathrm{R}=0.889)$ of $150 \mathrm{~m}$ run regarding $100 \mathrm{~m}$ and $200 \mathrm{~m}$, respectively, allow to conclude that sprint endurance development is a key factor for the result in both events.

5. The relationship between the series of $150 \mathrm{~m}$ and $300 \mathrm{~m}$ aimed at developing sprint- and speed endurance indicates the necessity of such type of effort, and its underestimation could lead to unsatisfactory results.

The research carried out by using AST efforts indicates that this type of training could help the speed development of junior athletes by improving the neuromuscular capacity of the sprinters.

\section{References}

1. Bachero-Mena B., Gonzalez-Badillo J.J. Effects of Resisted Sprint Training on Acceleration with three Different Loads Accounting for 5, 12.5, and $20 \%$ of Body Mass. The Journal of Strength \& Conditioning Research, 2014, vol. 28 (10), pp. 2954-2960. DOI: 10.1519/JSC. 0000000000000492

2. Bachev V., Gadev M., Groshev O., Yordanov P., Zlatev B. Computer-Aided Research and Analysis of Biomechanical Indicators in Acceleration of Sprint Running. Human. Sport. Medicine, South Ural State University, 2018, vol. 18, no. 1, pp. 95-102. DOI: 10.14529/hsm180108

3. Corn R.J., Knudson D. Effect of ElasticCord Towing on the Kinematics of the Acceleration Phase of Sprinting. J Strength Cond. Res., 2003, vol. 17 (1), pp. 72-75. DOI: 10.1519/15334287(2003)017<0072:EOECTO >2.0.CO;2

4. Dimitrov D. Biomechanical Indicators in Start and Start Acceleration in Dash Sprint. Sofia, Crisan S Publ., 2013. 130 p. (in Bulgarian)

5. Ebben W., Davies J.A., Clewien R.W.H. Effect of the Degree of Hill Slope on Acute Downhill Running Velocity and Acceleration. The Journal of Strength \& Conditioning Research, 2008, vol. 22 (3), pp. 898-902. DOI: 10.1519/JSC.0b013e31816a4149. 


\section{Спортивная тренировка}

6. Gadev M. Interrelation Between the Sports Result with Main Factors of Performance of Elite Sprinters. $9^{\text {th }}$ FIEP European Congress, $7^{\text {th }}$ International Scientific Congress "Sport, Stress, Adaptation" 9-12 October 2014, Sofia, Bulgaria, pp. 539-542.

7. Gadev M. The Technics of Dash Sprint, Sofia, Bolid Ins Publ., 2015. 176 p. (in Bulgarian).

8. Hicks D. Resisted and Assisted Sprint Training: Determining the Transfer to Maximal Sprinting. New Studies in Athletics, 2017, vol. 32:1/2 (1), pp. 35-52.

9. Jakalski K. The Pros and Cons of Using Resisted and Assisted Training Methods with High School Sprinters: Parachutes, Tubing, and Towing. Track Coach, 1998, vol. 144, pp. 4585-4589.

10. Kawamori N. Effects of Weighted Sled Towing with Heavy Versus Light Load on Sprint Acceleration Ability. $J$ Strength \& Cond. Res., 2014, vol. 28(10), pp. 2738-2745. DOI: 10.1519/JSC.0b013e3182915ed4

11. Kawamori N., Newton R., Nosaka K. Effects of Weighted Sled Towing on Ground Reaction Force During the Acceleration Phase of Sprint Running. J. Sport Sci., 2014, vol. 32 (12), pp. 1139-1145. DOI: 10.1080/02640414.2014. 886129

12. Lockie R.G., Murphy A.J., Schultz A.B. The Effects of Different Speed Training Protocols on Sprint Acceleration Kinematics and Muscle Strength and Power in Field-Sport Athletes. The Journal of Strength \& Conditioning Research, 2012, vol. 26 (6), pp. 1539-1550. DOI: $10.1519 /$ JSC.0b013e318234e8a0

13. Lockie R.G., Murphy A.J., Spinks C.D. Effects of Resisted Sled Towing on Sprint Kinematics in Field-Sport Athletes. The Journal of Strength \& Conditioning Research, 2003, vol. 17(4), pp. 760-767. DOI: 10.1519/15334287(2003)017<0760:EORSTO >2.0.CO;2

14. Maćkała K., Fostiak M, Kowalski K. Selected Determinants of Acceleration in the $100 \mathrm{~m}$ Sprint. Journal of Human Kinetics, 2015, vol. 24 (2), pp. 135-148. DOI: 10.1515/hukin2015-0014

15. Majumdar A.S., Robergs R.A. The Science of Speed: Determinants of Performance in the $100 \mathrm{~m}$ Sprint. International Journal of Sports Science \& Coaching, 2011, vol. 6(3), pp. 479-493. DOI: 10.1260/1747-9541.6.3.479
16. Maulder P.S., Bradshaw E.J., Keogh J.W. Kinematic Alterations Due to Different Loading Schemes in Early Acceleration Sprint Performance From Starting Blocks. The Journal of Strength \& Conditioning Research, 2008, vol. 22 (6), pp. 1992-2002. DOI: 10.1519/JSC. 0b013e31818746fe

17. Mero A., Komi P. Force-, EMG-, and eElasticity- Velocity Relationships at Submaximal, Maximal and Supramaximal Running Speeds in Sprinters. European Journal of Applied Physiology \& Occupational Physiology, 1986, vol. 55 (5), pp. 553-561. DOI: 10.1007/BF00421652

18. Mero A., Komi P.V. Effects of Supramaximal Velocity on Biomechanical Variables in Sprinting. Human Kinetics, 1985, vol. 1 (3), pp. 240-252. DOI: 10.1123/ijsb.1.3.240

19. Mero A., Komi P.V., Gregor R.J. Biomechanics of Sprint Running. A Review. Sports Medicine, 1992, vol. 13, pp. 376-392. DOI: 10.2165/00007256-199213060-00002

20. Pavlović R. Differences in Time of Start Reaction and Achieved Result in the Sprint Disciplines in the Finals of the Olympic Games in London and the World Championship in Moscow. Sport Scientific and Practical Aspect, 2015, vol. 12 (1), pp. 25-36.

21. Popova S. Short Distance Running. National Sports Academy Publ. House, 1997. $56 \mathrm{p}$.

22. Rumpf M.C., Cronin J.B., Pinder S.D., Oliver J. Effect of Different Training Methods on Running Sprint Times in Male Youth. Human Kinetics Journal, 2012, vol. 24 (2), pp. 170-186. DOI: 10.1519/JSC.0000000000001245

23. Stoyanov H. Competition Model Characteristics of Elite Male Sprinters. New Studies in Athletics, 2014, vol. 29 (4), pp. 53-56.

24. Stoyanov H., Dimitrov A.T., Dimitrov D. Possibilities for Development of Effective Running Technique by Means of Different Training Intensities. Journal "Track and Field Athletic" National Sports Academy, Sofia, 2003, vol. 1 (2), 10 p. (in Bulgarian)

25. Stoyanov H., Dimitrov D. Biomechanical Analysis of Sprint Running. Tip Top Press., 2017. $151 \mathrm{p}$.

26. Stoyanov H., Kalomiris M. Training Model for Improvement of the Maximum Speed in Elite Sprinters. Sport \& Nauka (Sport \& Science), 2009, vol. 2, pp. 33-36. (in Bulgarian)

Received 21 May 2019 


\title{
ВЛИЯНИЕ АССИСТИРОВАННЫХ ТРЕНИРОВОК НА СПЕЦИАЛЬНУЮ БЕГОВУЮ ПОДГОТОВКУ ЮНИОРОВ-СПРИНТЕРОВ НА 100 И 200 м
}

\author{
Х.T. Стоянов \\ Спортивный клуб «Академик», е. Софрия, Болгария
}

\begin{abstract}
Цель. Цель данного исследования - выявить эффективность инструментов ассистированных тренировок для улучшения наиболее важных показателей, влияющих на развитие скорости и результаты забегов на 100 и 200 м у спринтеров-юниоров. Эффективность ассистированных тренировок для развития скорости, максимальной скорости и скоростной выносливости была установлена с помощью специальных заданий. Материалы и методы. В исследовании принимали участие 8 спортсменов-юниоров. Продолжительность исследования составляла 7 недель, из которых 4 недели - предсоревновательный мезоцикл и 3 недели - соревновательный мезоцикл. Исследование сосредоточено на инструментах ассистированных тренировок, имеющих первостепенное значение для результатов забегов на 100 и 200 м. Эффективность использования данных инструментов для развития скорости, максимальной скорости и скоростной выносливости была установлена за счет выявления корреляций между ними. Результаты. По результатам исследования было установлено, что забеги на 30 м с использованием инструментов ассистированных тренировок улучшили максимальную скорость и стартовое ускорение. Была выявлена статистически значимая корреляция между скоростью в ассистированном забеге на 30 м и результатами забега на 100 м, что подтвердило эффективность использования инструментов ассистированных тренировок как для развития стартового ускорения, так и максимальной скорости. Также было выявлено, что результаты забега на 200 м зависели от времени ассистированного забега на 30 м и забега на 100 м. Выводы. Результаты исследования продемонстрировали, что использование инструментов ассистированных тренировок способствовало улучшению скорости спортсменов за счет развития нервных и мышечных резервов юных спринтеров.
\end{abstract}

Ключевые слова: ассистированная тренировка, забег на 100 и 200 м, развитие максимальной скорости, спринтерь-юниоры.

Христо Стоянов, Ph.D., главный тренер, спортивный клуб «Академик». Бульвар Климента Oxридского, 9, 1756, г. София, Болгария. E-mail: info@akademik-bg.com, ORCID: 0000-0001-6129-8056.

Поступила в редакцию 21 мая 2019 г.

\section{ОБРАЗЕЦ ЦИТИРОВАНИЯ}

Stoyanov, H.T. Effect of Assisted Training on the Special Running Preparation of Junior Sprinters for 100 and $200 \mathrm{~m} /$ H.T. Stoyanov // Человек. Спорт. Медицина. - 2019. - Т. 19, № 3. - C. 74-79. DOI: $10.14529 / \mathrm{hsm} 190309$

\section{FOR CITATION}

Stoyanov H.T. Effect of Assisted Training on the Special Running Preparation of Junior Sprinters for 100 and 200 m. Human. Sport. Medicine, 2019, vol. 19, no. 3, pp. 74-79. DOI: 10.14529/hsm190309 